\title{
Influence of Forest Management System FSC, PEFC and ISO 38200:2018 Toward Business Performance at Wood and Paper Industries in Sumatera Indonesia
}

\author{
Agus Purwanto*, Otto Berman Sihite, Evy Yanthy, Leo Hutagalung \\ Post Graduate, Pelita Harapan University, J1. MH. Thamrin Boulevard 1100, Kelapa Dua, Kec. Karawaci, Kota Tangerang, Banten 15811, Indonesia
}

DOI: $10.36348 /$ sjbms.2019.v04i12.005 $\quad$ | Received: 06.12.2019| Accepted: 13.12.2019| Published: 20.12 .2019

*Corresponding author: Agus Purwanto

Abstract

The purpose of this study was to analysis the effect of the implementation of The Programme for the Endorsement of Forest Certification (PEFC), FSC (Forest Stewardship Council) and ISO 38200:2018 to business performance for paper and wood industries. This research was conducted in several companies that produced paper and use woods raw materials in Sumatera of Indonesia with 337 respondents of companies that have plan to implement the ISO 38200:2018, PEFC and FSC . The research background is due to lack of research on the benefits of FSC, PEFC and ISO 38200:2018 in paper and wood companies in Sumatera of Indonesia. The data collection was carried out by distributing questionnaires on september until desember 2019 and analyzing data processing use Structural Equation Model (SEM) and software Linear Structural Model (LISREL) version 8.70. The results show that the implementation of PEFC, FSC and ISO 38200:2018 has significantly influenced business performance such as increase customer satisfaction index, increase sales, increase productivity and safety and employee satisfaction.

Keywords: Chain of Custody, FSC, PEFC, ISO 32800:2018, Business Performance

Copyright @ 2019: This is an open-access article distributed under the terms of the Creative Commons Attribution license which permits unrestricted use, distribution, and reproduction in any medium for non-commercial use (NonCommercial, or CC-BY-NC) provided the original author and source are credited.

\section{INTRODUCTION}

PEFC, FSC and A new standard for supporting responsible use of wood and wood products has just been published ISO 38200:2018 Chain of custody of wood and wood-based products. Deforestation and forest degradation are ravaging our planet, This new ISO standard and PEFC, FSC is for tracing wood and wood products back to its sources and will help to provide this information. PEFC, FSC and ISO 38200:2018, Chain of custody of wood and wood-based products contain the requirements for a chain of custody of wood and wood-based products that allows users to trace the origininality of wood and wood products every step along the supply chain (Iso.org, 2019).

PEFC, FSC and Chain of Custody (CoC) certification is a certification system developed to verify the origin of forest products used in the production process, originating from responsible sources, there are mechanisms that can trace the origin of forest products and ensure they are safe from mixing of uncertified raw materials. Because it relates to forest products, the chain of custody certification is applied to all supply chain companies, from which wood is processed, formed, packaged, and transported to the hands of consumers. FSC, PEFC and ISO 38200 Chain of custody certificates can be given to companies if the certification body can verify the origin of the wood used in production comes from certified sources, in addition to production, handling and packaging, storage until the hands of consumers are not mixed with other raw materials that are not certified (FSC.org, 2019).

The purpose of monitoring forest resources is to reduce unplanned deforestation, restore and rehabilitate degraded forests, sustainable management of forests, and evaluate the function of carbon sequestration by forests, forested lands and trees outside the forest to moderate the global climate [1]. Protecting tropical forests is becoming increasingly urgent because of the decline in forest areas by $6 \%$ and $17 \%$ global carbon dioxide emissions [2]. More is needed about ways to reduce forest loss and maintain oxygen stocks 
[3-5]. Most of the forest becomes deforestation and high forest degradation [6]. Deforestation contributes greatly to increasing global greenhouse gas emissions and resulting in climate change [7]. Many people who live in or near these forests are highly dependent on forest resources and their livelihoods are threatened by deforestation [8].

WWF [9] summarizes that working in the forest industry has become the largest beneficiary of forest certification through improvements in the implementation of health and safety laws and guidelines. Dependence on well-trained staff, supported by increased training and training compliance with social taxation requirements has led to proven working conditions for those working in certified forests. Newsom \& Hewitt [10] examined and found that $91 \%$ of certified companies were required to increase the training of their workers, $82 \%$ increase safety, and as much as $64 \%$ increase workers' wages. Hirschberger Research [9] as many as 183 out of 12 Russian forest companies that are certified covering a total area of more than 3.5 million ha found that the results of the forest certification strengthen work rights for forest company workers. Maria Tysiachniouk [11] examined the majority of forest certified regional companies as workers' protection increased and postponement of salary decreased. Workers understand that certification can be used as a social protection tool.

There have been many companies that have certified forest and in 2019 companies in Indonesia have already certified as many as 580 certified [9]. many companies that are forest certified and in 2019 companies in indonesia including Central Java Province Indonesia which have been certified, the main purpose of implementing PEC, PEFC and ISO 38200:2018 is to fulfill government regulations and also requests from customers, there are several objectives to be achieved namely increase business performance such as customer satisfaction index, increase sales, increase productivity and safety and employee satisfaction.
The purpose of this study was to determine the effect of the implementation of PEFC, FSC and ISO 38200:2018 on business performance. The urgency of this study is the first because there has not been any study on the effect of PEFC, FSC and ISO 38200:2018 specifically on wood industries in Banten. The novelty of this research is the first study that analyzes the effect of FSC, PEFC and new standard ISO 38200:2018 implementation on business performance of paper and wood industries in Sumatera Indonesia.

\section{METHOD}

The Data analysis of this research using the Structural Equation Model (SEM) using a Linear Structural Model (LISREL) version 8.70 software. William and Gavin [12] using LISREL to test the relationship between the latent variables and indicators indicators. Construct validity and reliability of the indicators in this study conducted by Confirmatory Factor Analysis (CFA). Testing the validity and reliability of the instrument was performed using confirmatory factor analysis to obtain valid and reliable data. Second-order confirmatory factor analysis (2nd Order CFA) is a measurement model consists of two levels. The first level of analysis performed on the latent constructs all aspects of the indicators and the analysis is done of latent constructs to construct its aspects. Through the CFA not only be done testing the validity of a construct (Construct Validity) but also reliability testing constructs (Construct Reliability). The construct has good reliability is if the value of Construct Reliability $(\mathrm{CR}) \geq 0.70$ and variance extracted values $\geq$ 0.50 .

Data This study is based on questionnaires distributed in 337 respondents from 15 of paper and wood industries companies di Sumatera that have plan to implement PEFC, FAC and ISO 38200:2018 Management System in Sumatera Indonesia. Based on the previous studies and the purpose of writing this study, it created a research model as follows:

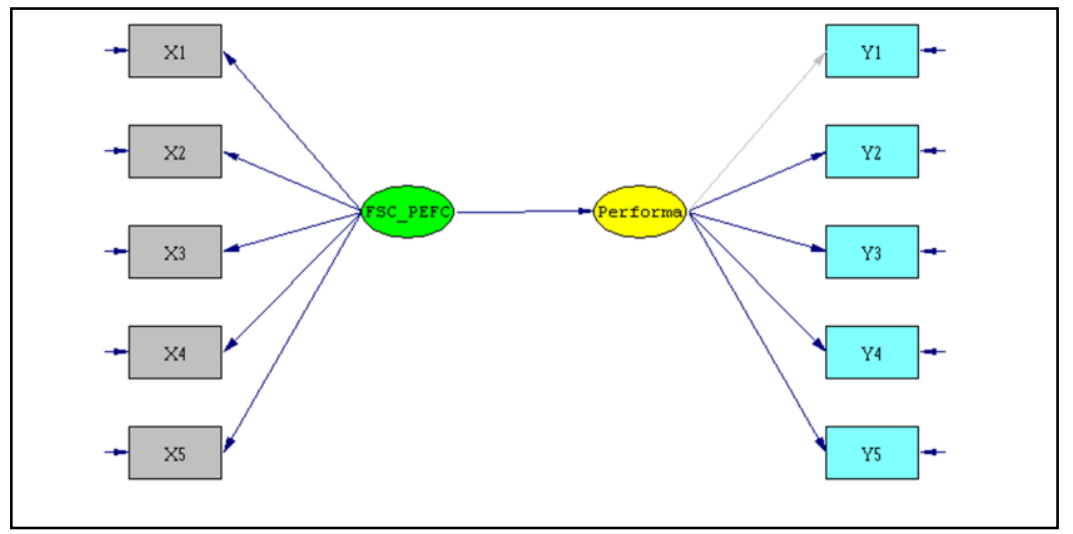

Fig-1: Model of Research

Note: The figure 1 is derived from the output of the Lisrel program (authors, 2019) 
Based on the above research model made the following hypotheses:

1. Ho: There is a no significant and positive relationship between the implementation of PEFC, FSC and ISO 38200:2018 (X) to the Business Performance (Y).

2. H1: There is a significant and positive relationship between the implementation of PEFC, FSC and ISO 38200:2018 (X) to the Business Performance (Y).

Based on the hypothesis of the indicator - an indicator of the variables used in this study are indicators of Dependent Variables X ( Implementation of PEFC, FSC and ISO 38200:2018), namely management system (X1), Documentation (X2), material and products records (X3), Sales (X4), Risk Assesment (X5) (ISO.org,2019), Indicators of Dependent Variables Business Performance (Y), namely as increase customer satisfaction index (Y1), increase sales (Y2), increase productivity (Y3), safety (Y4) and employee satisfaction (Y5).
Table-1: Profile of Respondents

\begin{tabular}{|l|l|l|l|}
\hline Job Title & Man & Woman & Total \\
\hline Top Management & 46 & 36 & 82 \\
\hline ISO Coordinator & 25 & 16 & 41 \\
\hline Manager & 54 & 37 & 91 \\
\hline Supervisor & 71 & 52 & 123 \\
\hline Total & 196 & 141 & 337 \\
\hline
\end{tabular}

Note: The respondent profile table is derived from a summary of the questionnaire returned (authors, 2019)

The distribution of questionnaire data from March until December 2019, data on companies that implemented the FSC, PEFC and ISO 38200.

\section{RESULTS AND DISCUSSION}

The first step is to create a syntax program on Lisrell software after that the program is run to get the loading factor of PEFC, FSC and ISO 38200:2018 variable $(\mathrm{X})$ and Business Performance Variable (Y) and to determine the $t$ value of each variable. The data analysis by Structural Equation Model (SEM) using a Software Linear Structural Model (LISREL) version 8.70 of Joreskog and Sorbom [13], and the results of analusis are in the following Figure.

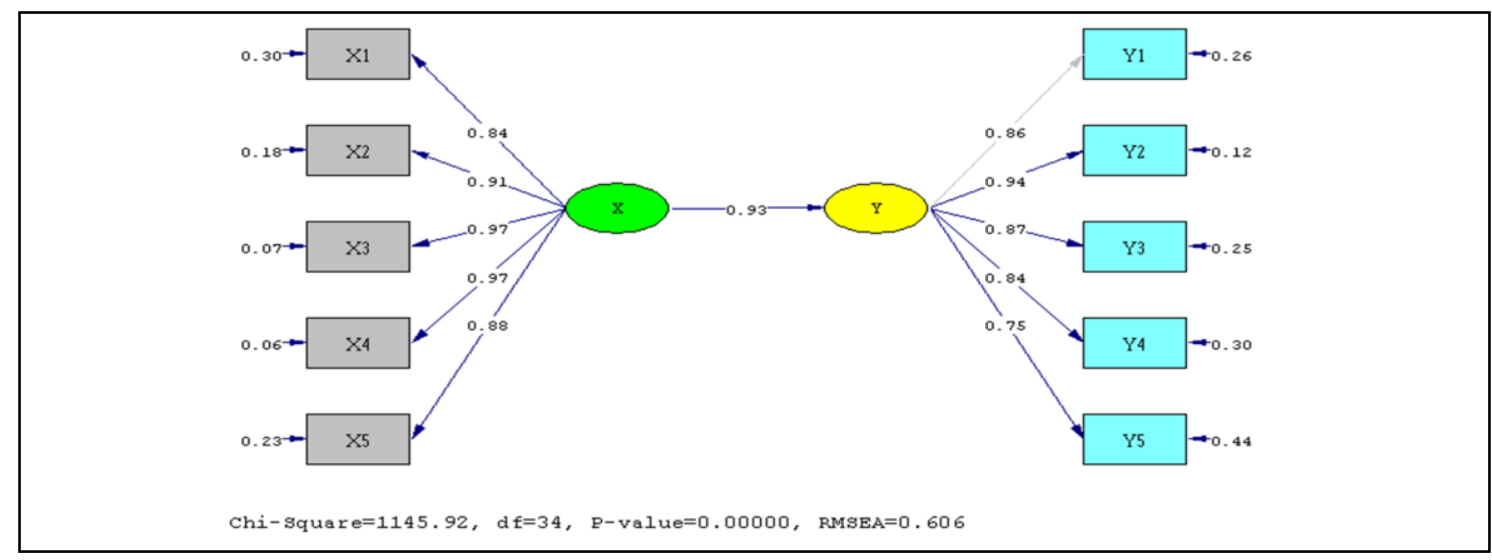

Fig-2: Loading factor Value Indicator

Note: The figure comes from the output of the Lisrel program processing (authors, 2019)

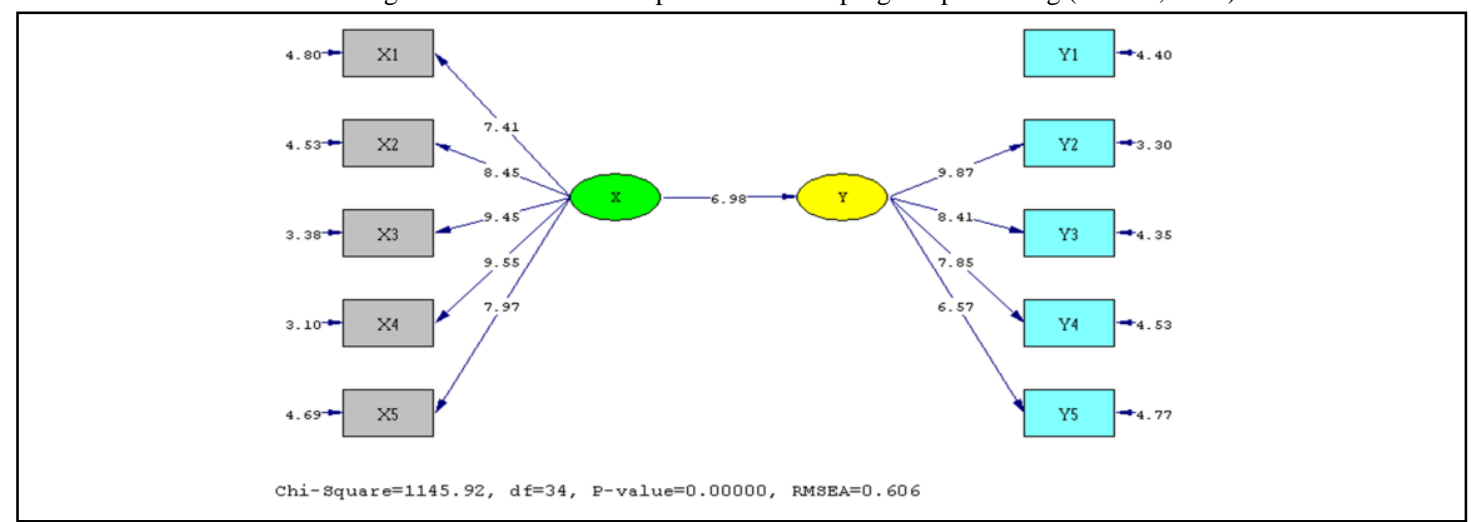

Fig-3: t-Value Indicator

Note: The figure comes from the output of the Lisrel program processing (authors, 2019) 
Based on Figure $2 \& 3$ is concluded that no error variance negative value, and the value of the indicator FSC, PEFC and ISO 38200 above the loading factor of $0.5(>0.5)$ and for value loading factor $<0.5$ will be issued. The entire value of $t$ which to test the significance of the value of the loading factor of greater than $1.96(>1.96)$.
It is that all valid and significant indicator. Then the results of the output lisrell of each indicator and loading factor are summarized in the table for analysis of validity and reliability ummary of the results of the analysis can be seen in the following Table:

Table-2: Results of 2nd Order Analysis Indicators CFA Construct Validity

\begin{tabular}{|c|l|l|l|l|}
\hline Variable & Indicator & Loading Factor & T-Value & Remark \\
\hline \multirow{3}{*}{$\begin{array}{c}\text { PEFC, FSC \& ISO 38200:2018 } \\
\text { ( X) }\end{array}$} & $\mathrm{X} 1$ & 0.68 & 7.41 & Valid \& Significant \\
\cline { 2 - 5 } & $\mathrm{X} 2$ & 0.81 & 8.45 & Valid \& Significant \\
\cline { 2 - 5 } & $\mathrm{X} 3$ & 0.81 & 9.45 & Valid \& Significant \\
\cline { 2 - 5 } & $\mathrm{X} 4$ & 0.87 & 9.55 & Valid \& Significant \\
\cline { 2 - 5 } & $\mathrm{X} 5$ & 0.69 & 7.93 & Valid \& Significant \\
\hline \multirow{3}{*}{$\begin{array}{c}\text { Berformance } \\
\text { ( Y) }\end{array}$} & $\mathrm{Y} 1$ & 0.71 & & \\
\cline { 2 - 5 } & $\mathrm{Y} 2$ & 0.78 & 9.87 & Valid \& Significant \\
\cline { 2 - 5 } & $\mathrm{Y} 3$ & 0.70 & 8.41 & Valid \& Significant \\
\cline { 2 - 5 } & $\mathrm{Y} 4$ & 0.69 & 7.85 & Valid \& Significant \\
\cline { 2 - 5 } & $\mathrm{Y} 5$ & 0.67 & 6.57 & Valid \& Significant \\
\hline
\end{tabular}

Note: The table comes from the output of the Lisrel program processing (authors, 2019)

Based on the above test results showed that the value of the loading factor is obtained entirely above 0.5 (>0.5), and all the $t$ value obtained is more significant than $1.96(>1.96)$. A summary of the results of the above analyses can be seen in Table- 3 .

Table-3: Analysis for the 2nd Order CFA OCB Construct Validity

\begin{tabular}{|l|l|l|l|l|}
\hline Variable & Variable & Loading Factor & T-Value & Remark \\
\hline ISO 38200, PEFC, FSC & $\mathrm{X}$ & 0.93 & 6.98 & Valid \& Significant \\
\hline
\end{tabular}

Note: Table comes from the output of the Lisrel program processing (authors, 2019)

These results can be concluded that PEFC, FSC and ISO 38200:2018 (X) has valid and significant. Results of validity are also reinforced by the value of Chi-Square that generates a value of 100.44. The next step to calculate the value Construct Reliability (CR) and Variance Value entrance (VR), Construct reliability is a measure of the internal consistency of indicators that show the formation of a variable degree in the variable formed. Extracted variance is a measure of how much of the variance of the indicators were removed by the variable created. Two approaches can be made to assess the reliability of the measurement model is test construct reliability and variance extracted for each latent variables (Hair et al. 2010). the next step is to summarize the value of construct reliability and variance extracted from the loading factor value of each variable in the following table.

Table-4: Results of 2nd Order Analysis Construct Reliability

\begin{tabular}{|c|c|c|c|c|c|}
\hline Indicator & Loading Factor & Loading Factor2 & 1-Loading Factor2 & $\mathbf{C R}$ & VE \\
\hline Management System (X1) & 0.68 & 0.46 & 0.54 & \multirow[t]{5}{*}{0.87} & \multirow[t]{5}{*}{0.65} \\
\hline Documentation (X2) & 0.81 & 0.66 & 0.34 & & \\
\hline Material and Product Record (X3) & 0.81 & 0.66 & 0.34 & & \\
\hline Sales ( X4) & 0.87 & 0.76 & 0.24 & & \\
\hline Risk Assesmenst (X5) & 0.69 & 0.48 & 0.52 & & \\
\hline Customer Satisfaction Index (Y1) & 0.71 & 0.50 & 0.50 & \multirow[t]{5}{*}{0.87} & \multirow[t]{5}{*}{0.68} \\
\hline Sales Increase (Y2) & 0.78 & 0.61 & 0.39 & & \\
\hline Productivity (Y3) & 0.70 & 0.49 & 0.51 & & \\
\hline Safety (Y4) & 0.69 & 0.48 & 0.52 & & \\
\hline Employee Satisfaction (Y5) & 0.67 & 0.45 & 0.55 & & \\
\hline
\end{tabular}

Note: Table comes from the output of the Lisrel program processing (authors, 2019) 
Based on the calculation formula CR construct reliability was obtained results and indicators VE for PEFC, FSC and ISO 38200:2018 (OCB) of 0.87 (CR) $\geq$ 0.70 and $0.655(\mathrm{VE}) \geq 0.50$. and concluded that the variable $(\mathrm{X})$ has good reliability and value constructs have good reliability. Businnes Performance Indicators (OP) of $0.87(\mathrm{CR}) \geq 0.70$ and $0.68(\mathrm{VE}) \geq 0.50$. and concluded that the Business Performance has good reliability and value constructs have good reliability. Therefore, based on the results of the analysis of the reliability calculation can be concluded that the reliability of the whole is a good indicator and conclude that the research meets the requirements of all phases of testing. The next step is to carry out the Analysis of Goodness of Fit (GOF), GOF data obtained from the results of the software execution.

\section{Analysis Goodness of Fit (GOF)}

Test the suitability of the model in the overall model fit about the analysis of statistical GOF value generated by the program lisrel, for the relevance of the model (model fit) are good enough and for its model fit the criteria as shown in Table-5.

Table-5: Goodness of Fit

\begin{tabular}{|l|l|l|l|}
\hline \multicolumn{1}{|c|}{ Indeks Fit } & Value & Value Standard & Remark \\
\hline Chi-Square & 1145 & $>0.5$ & Fit \\
\hline Root Mean Square Error of Approximation (RMSEA) & 0.04 & $<0.08$ & Fit \\
\hline Normed Fit Index (NFI) & 0.98 & $>0.90$ & Fit \\
\hline Non-Normed Fit Index (NNFI) & 0.96 & $>0.90$ & Fit \\
\hline Comparative Fit Index (CFI) & 0.93 & $>0.90$ & Fit \\
\hline Incremental Fit Index (IFI) & 0.93 & $>0.90$ & Fit \\
\hline
\end{tabular}

Note: Table comes from the output of the Lisrel program processing (authors, 2019)

Based on the results of the analysis above can be seen that all fit indices stated that the model fit. These results indicate that the variable is declared valid and reliable so that it can be concluded that the overall model is still a good match. Model equation (Structural Equations) linear from 8.70 LISREL software obtained as follows:

\begin{tabular}{|c|c|}
\hline \multicolumn{2}{|c|}{$Y=0.92 * X$, Errorvar. $=0.14, R^{2}=0.86$} \\
\hline (0.10) & $(0.037)$ \\
\hline 9.18 & 3.76 \\
\hline
\end{tabular}

Based on the results from all the above analysis, it can be seen that the implementation of PEFC, FSC and ISO 38200:2018 (X) is a positive and significant effect on Business Competitiveness with $\mathrm{t}$ value equal to 9.18 The goodness of fit models is produced pretty good with chi-square value of $86 \%$. For the virtue of fit criteria, the other also already qualified as needed. Rated $\mathrm{R}$ Square of 0.67 means the Implementation of PPEFC, FSC and ISO 38200:2018 have affect the business Competitiveness by $86 \%$ while other factors influence $14 \%$. So summarized and obtained the following regression equation OP (Business Competitiveness) $=0.86 \mathrm{x}$ PEFC, COC and ISO 38200:2018 + Error

\section{DISCUSSION AND CONCLUSION}

Based on the analysis of the results of research can be concluded that the implementation of the PEFC, FSC and ISO 38200:2018 has a positive and significant impact on influenced business competitiveness performance such as increase customer satisfaction index, increase sales, increase productivity and safety and employee satisfaction so that it will increase the company's profit The research object not only in Banten province but could also be extended to other provinces. The results of this study of implementation of the PEFC, FSC and ISO 38200 management system has an influence on business competitiveness so that companies that have not implemented it are recommended to immediately implement it, this study reinforces the results of previous studies

This study contributes to the research into the benefits of PEFC, FSC and ISO 38200:2018 certification, The limitation of this study is that it does not discuss financial performance indicators, so in future research financial performance can be measured over a certain period of time. Other than that,a comparison of the financial performance of PEFC, FSC and ISO 38200:2018 Certificate holders can be made. PEFC, FSC and ISO 38200:2018 certification applies to all organizations that trade, process or produce wood and forest products. The benefits of implementing PEFC, FSC and ISO 38200:2018 certification namely maintaining customers are the main benefits of certification, increasing new customers, increase in exports, increase company image, profit and increase, commitment to environmental responsibility which enhance the company's image, promote, sustainable use of forest resources, improve communication with customers, prevent illegal logging, and improvemanagement efficiency.

The results of the study show that ISO PEFC, FSC and 38200:2018 certification is a prerequisite for competitiveness for companies. One of the benefits of this research is to convince the owners of timber and processing companies to get PEFC,FSC and ISO 38200:2018 certified because the benefits of its application have been tested and also as a form of 
compliance with laws and regulations so as to enhance the good image of the company

\section{LIMITATION}

This study has several limitations, the sample is not enough representative of the target population, the number of samples that are not much due to limited time and cost ofresearch, the object of this study is only industry companies in Sumatera Island even though more other companies have implemented in othes Provincies. This study has limited time and the number of respondents only 337 employees have not convinced to generalize the results of this study. Software used for data analysis is Lisrel and a lot of people did not yet familiar with this software. This study didn`t not discuss about financial and commercial indicators so it's cannot be known the real financial benefits of applying ISO 38200:2018, for the following research to discuss financial indocators by comparing the financial condition of PEFC, FSC and ISO 38200:2018 certified and uncertified companies. This research only examines the paper industry even though many companies are implementing PEFC, FSC and ISO 38200:2018 such as wood distributors, wood factories and others. For further research it is advisable to examine companies throughout the chain from paper and wood to end users

\section{REFERENCES}

1. Fujita, K., \& Shaw, R. (2010). Chapter 7 Forest management as an adaptation option in mountain areas of Japan. In Climate Change Adaptation and Disaster Risk Reduction: An Asian Perspective (pp. 127-145). Emerald Group Publishing Limited.

2. Baccini, A. G. S. J., Goetz, S. J., Walker, W. S., Laporte, N. T., Sun, M., Sulla-Menashe, D., ... \& Samanta, S. (2012). Estimated carbon dioxide emissions from tropical deforestation improved by carbon-density maps. Nature climate change, 2(3), 182.

3. Brown, M. I. (2013). Redeeming REDD: Policies, Incentives and Social Feasibility For Avoided Deforestation. Earthscan, London.

4. Sills, E. O., Atmadja, S. S., de Sassi, C., Duchelle, A. E., Kweka, D. L., Resosudarmo, I. A. P., \& Sunderlin, W. D. (Eds.). (2014). REDD+ on the ground: A case book of subnational initiatives across the globe. Cifor. Bogor, Indonesia.

5. Lee, D., Llopis, P., Waterworth, R., Roberts, G., \& Pearson, T. (2018). Approaches to REDD+ Nesting: Lessons Learned from Country Experiences. World Bank, Washington, DC.

6. Sloan, S., \& Sayer, J. A. (2015). Forest Resources Assessment of 2015 shows positive global trends but forest loss and degradation persist in poor tropical countries. Forest Ecology and Management, 352, 134-145.

7. Harris, N. L., Brown, S., Hagen, S. C., Saatchi, S. S., Petrova, S., Salas, W., ... \& Lotsch, A. (2012). Baseline map of carbon emissions from Deforestation in tropical regions. Science, 336(6088), 1573-1576.

8. Sunderlin, W.D., Angelsen, A., Belcher, B., Burgers, P., Nasi, R., et al., 2005. Livelihoods, forests, and conservation in developing countries: an overview. World Dev. 33, 1383-1402.

9. Hirschberger, P. (2005). The Effects of FSCcertification in Latvia: an analysis of CARs. WWF Forest Programme.29 p. http://www.panda.org/downloads/forests/fscanalys islatvia.pdf (as of June 2008).

10. Newsom, D., \& Hewitt, D. (2005). The Global Impacts of SmartWood Certification. Final Report ofthe TREES Program for the Rainforest Alliance. http://www.rainforestalliance. org/programs/forestry/perspectives/documents/sw impacts.pdf (as of June 2008).

11. Tysiachniouk, M. (2005). Forest Certification in Russia. (Center for Independent Social Research St. Petersburg, Russia); Paper presented at Yale Forest Certification Symposium. published by Yale school of forestry \&environmental studies.http://www.yale.edu/forestcertification/sy mposium/pdfs/Book\%20Chapters/12\%20Russia.p df (as of June 2008)

12. Williams, G. (2004). Structural Equation Modeling Methods in Strategy Research: Application and Issue. Research Methodology in Strategy and Management (Research Methodology in Strategy and Management, Vol. 1), Emerald Group Publishing Limited, Bingley, 303-346.

13. Joreskog, K. G., \& Sorbom, D. (2008). LISREL (Version 8.8). Chicago, IL: Scientific Software International. 